\title{
IN VITRO OVICIDAL ACTIVITY OF COMBINATION Illicium verum EXTRACT AND COCONUT OIL AGAINST Pediculus humanus capitis
}

\author{
Yunita Armiyanti ${ }^{1}$, Anzil Aziza' ${ }^{2}$, Ika Rahmawati Sutejo ${ }^{3}$ \\ ${ }^{1}$ Department of Parasitology, Faculty of Medicine University of Jember, Indonesia \\ ${ }^{2}$ Medical Education Program, Faculty of Medicine University of Jember, Indonesia \\ ${ }^{3}$ Department of Biochemistry, Faculty of Medicine University of Jember, Indonesia \\ Corresponding author: yunita.fk@unej.ac.id
}

\begin{abstract}
Permethrine is still the main therapy for human head infestation Pediculosis capitis in several countries, including Indonesia. However,permethrine is not effective for egg stage. Therefore, alternative therapy from herbs are needed for the treatment of head lice which is effective for both egg and adult stage. The aim of this study was to determine the efficacy of Illicium verum extract and coconut oil formula against eggs of head lice. An in vitro immersion test was applied with four treatment group (Illicium verum extract and coconut oil formula with four different composition) as well as negative control group (distilled water) and positive control group (permethrine 1\%) against eggs of head lice. The eggs of head lice were immersed for $0.5,1$, or $2 \mathrm{~min}$ in $1 \mathrm{ml}$ of each solution. Mortality rates of the eggs were recorded after 5 days of incubation. The formula of Illicium verum extract and palm oil with composition 60:40 had the best efficacy with mortality rate of head lice eggs reached $86,67 \%$, after immersion for 2 minutes. The combination of Illicium verum extract and coconut oil could be an alternative ovicide, but this formula requires precise composition which can be applied for Pediculus humanus capitis.
\end{abstract}

Keywords: head lice, ovicide, Illicium verum, palm oil, efficacy

\section{Introduction}

Pediculosis capitis spreads throughout the world, both developed and developing countries, including Indonesia [1]. In Indonesia, pediculosis infest in girl's hair mostly, especially those who live in crowded communities such as Islamic boarding schools. Previous research by Lukman (2018) stated that as many as $74.6 \%$ of the 287 students at the Miftahul Ulum Islamic Boarding School in Jember Regency were infested with capitis pediculosis [2].

Treatment of head lice generally uses insecticides that are sold in the market, such as permethrin, hexachlorocyclohexane (lindane), malathion, and pyrethrin [3]. These insecticides have side effects that are harmful to humans, for example lindane has been reported to have neurotoxic side effects, including dizziness, seizures, and even death when used for a long time [4]. The incidence of head lice resistance to the insecticides permethrin, lindane, malathione, and pyrethrin has also been widely reported in the United States, United Kingdom, Australia and Argentina which causes less effective treatment [5].

The existence of side effects and resistance from chemical pediculocides requires an alternative treatment of natural pediculocide. Previous research conducted by Soonwera (2016) on natural insecticides showed that only Illicium verum (anise flower) was able to kill one hundred percent of head lice after six hours of experiments [5]. Coconut oil is also able to eradicate head lice with regular use [6]. The content of coconut oil, namely lauric acid, can be a natural insecticide [7]. Therefore, the combination of Illicium verum extract and coconut oil is expected to increase the effectiveness of the natural ovicides to head lice. 


\section{Methods}

The anise flower is extracted in the way described previously. The anise flower extract is mixed with coconut oil in a ratio of 30:70, 40:60, 50:50, and 60:40 using a $100 \mathrm{~mL}$ measuring cup based on previous research $[8,9]$. The mixture was added with $0.5 \mathrm{~mL}$ of dimethyl sulfoxide (DMSO) so that the liquid becomed homogeneous [10].

180 eggs of head lice that attached to the hair were divided into 18 groups with 10 nits each. Nits are attached to the object glass by using the tape. The object glass was then dropped until the nits were immersed in distilled water for negative control, $1 \%$ permethrin for positive control, and the test solution in the treatment group for 0.5 ; 1 ; or 2 minutes. Object glass was dried using filter paper and incubated at room temperature. Observations were made on the fifth day under a light microscope with 400x magnification after signs of removal of nymphs from control eggs. The egg was assesed to die when the operculum was closed or the operculum was open with the nymph inside [11].

The statistical tests used were the Kolmogorov-Smirnov normality test, Levene's homogeneity test of the equality of error variance test, and the oneway ANOVA test. The next test uses the probit test to determine the IC50 value of the mixture of anise flowers and coconut oil.

\section{Results}

Table 1. The mean percentage of lice egg mortality at immersion time was 0.5 ; 1 ; and 2 minutes

\begin{tabular}{|c|c|c|c|c|c|}
\hline \multirow{2}{*}{ Groups } & \multirow{2}{*}{ Treatment } & \multicolumn{3}{|c|}{$\begin{array}{l}\text { Average Mortality of Nits at } \\
\text { Immersion Time }(\%)\end{array}$} & \multirow{2}{*}{$\begin{array}{c}\text { Mean } \\
\text { Percentage of } \\
\text { Mortality }(\%)\end{array}$} \\
\hline & & $\begin{array}{c}\mathbf{0 , 5} \\
\text { minutes }\end{array}$ & $\begin{array}{c}1 \\
\text { minutes }\end{array}$ & $\begin{array}{c}2 \\
\text { minutes }\end{array}$ & \\
\hline K- & Aquades & 0 & 0 & 0 & 0 \\
\hline $\mathrm{K}+$ & Permethrin $1 \%$ & 3,33 & 6,67 & 30 & 13,33 \\
\hline P1 & $\begin{array}{l}\text { Anise flower:coconut oil } \\
30: 70\end{array}$ & 20 & 23,33 & 40 & 27,78 \\
\hline $\mathrm{P} 2$ & $\begin{array}{l}\text { Anise flower:coconut oil } \\
40: 60\end{array}$ & 23,33 & 30 & 50 & 34,44 \\
\hline P3 & $\begin{array}{l}\text { Anise flower:coconut oil } \\
50: 50\end{array}$ & 23,33 & 43,33 & 66,67 & 44,44 \\
\hline P4 & $\begin{array}{l}\text { Anise flower:coconut oil } \\
60: 40\end{array}$ & 70 & 90 & 100 & 86,67 \\
\hline
\end{tabular}

\section{Discussion}

Table 1 showed the treatment group has an increase in the average number of lice egg deaths higher than the negative control group and the positive control mainly in P4 (mixture of anise with coconut oil, ratio $60: 40$ ) of $86.67 \%$. Anise flower contains various compounds, such as resins, fats, tannins, terpenoids, limonene, estradol, safrol, timokuinones, flavonoids, glucosides, phenyl propanoids, and saponins [12]. Flavonoids have the properties as stomach poisoning [13]. Phenyl propanoid works by dissolving in membranes and disrupting the fluidity and function of cell membrane proteins [14]. Those effects may cause lice eggs death. Data analysis used the One Way ANOVA test showed the $\mathrm{p}$ value $=0.000(\mathrm{p}<0.05)$ which means that there were differences between groups. The results of the Post Hoc Tukey test in the P4 group of mixed anise flowers with coconut oil with the ratio of $60: 40$ showed a significant difference with the negative control group and the positive control group $(\mathrm{p}<0.05)$. This results showed that the P4 group had a higher ovicide effect than $1 \%$ permethin. Analysis with the Probit test to get the IC50 value of a mixture of 
anise flowers with coconut oil was $1.073 \%$ lower than permethrin which has an IC50 value of 3.3\% [15]. These results indicate that a mixture of anise and coconut oil was more effective as ovicide to lice eggs than permethrin.

\section{Conclusion}

The mixture of lawang flowers with coconut oil has the potential as an ovicide so that it can be a safe alternative for the treatment of pediculosis capitis.

\section{Reference}

[1] Al-Bashtawy, M., and F. Hasna. 2012. "Pediculosis Capitis Among Primary School Children in Mafraq Governorate, Jordan". East Mediterr Health Journal. Vol18(1), pp43-84.

[2] Lukman, N., Armiyanti Y., Agustina D. 2018. "Hubungan Faktor-Faktor Risiko Pediculosis capitis terhadap Kejadiannya pada Santri di Pondok Pesantren Miftahul Ulum Kabupaten Jember". Journal of Agromedicine and Medical Sciences. Vol4(2), pp102-109.

[3] Fadilah, H. 2015." Perbedaan Metode Ceramah dan Leaflet terhadap Skor Pengetahuan Santriwati tentang Pedikulosis Kapitis di Pondok Pesantren Al-Mimbar Sambongdukuh Jombang". Skripsi. Jakarta: Fakultas Kedokteran dan Ilmu Kesehatan UIN Syarif Hidayatullah.

[4] Burkhart, C. G., and C. N. Burkhart. 2006. "Safety and Efficacy of Pediculicides for Head Lice”. Expert Opin. Drug Saf. Vol5(1), pp169-179.

[5] Soonwera, M. 2016. "Toxicity of Five Herbal Extracts Against Head Louse (Pediculus humanus capitis De Geer.: Phtiraptera) in Vitro". International Journal of Agricultural Technology. Vol12(4), pp657-666.

[6] Alsasua, M. M. 2016. "Randomized Controlled Trial on The Effect of Coconut Oil, Vinegar Plus Cooking Coconut Oil Versus 1\% Permethrin Shampoo in The Treatment of Pediculosis". Pediatric Infectious Diseases Society of The Philippines Journal. Vol17(2), pp 4-13.
[7] Sarip, S. H. M., A. A. Aziz, H. Ya'akob, K. Puad. 2016. "Toxicological Effect of Lauric Acid Based Insecticide on The Reproduction System, Growth Development, and Feeding Activity of Aphids, Aphis gossypii Glover". International Journal of Biotechnology for Wellness Industries. Vol5, pp76-81.

[8] Vijayalakshmi, M., K. Periyanayagam, P. S. Lakshmana. 2010. "In Vitro Antilice Activity of Dichrostachys cinerea (L.)". Wight \& Arn. International Journal of PharmTech Research. Vol2(4), pp2210-2213.

[9] Rahayu, Y. S. E., and Widyoningsih. 2016. "Efektifitas Formulasi Ekstrak Sereh Wangi dan Minyak Kelapa Murni Sebagai Pembasmi Kutu Rambut". Jurnal Kesehatan Al-Irsyad. Vol9(1), pp35-43.

[10] Pavela, R. 2009. "Larvacidal Property of Essential Oils Against Culex quinquefascatatus Say (Diptera: Culicidae)". Industrial Crops and Products. Vol30, pp311315 .

[11] Gallardo, A., G. M. Cueto, C. Vassena, M. I. Picollo, A. C. Toloza. 2012. "Comparative Efficacy of New Commercial Pediculicides Against Adults and Eggs of Pediculus humanus capitis (Head Lice)". Parasitology Research. Vol110, pp1601-1606.

[12] Ali, R. M., A. S. Zainon, M. M. Nik, H. Norhar. 2010. "ASEAN Herbal and Medicinal Plants". Jakarta: ASEAN Secretariat.

[13] Pritacindy, A. P., Supriyadi, A. Kurniawan. 2017. "Uji Efektivitas Ekstrak Bawang Putih (Allium sativum) Sebagai Insektisida terhadap Kutu Rambut (Pediculus capitis)". Skripsi. Malang: Universitas Negeri Malang.

[14] Wink, M. 2012. "Medicinal Plants: A Source of Anti-Parasitic Secondary Metabolites". Molecules. Vol17, pp12771-12791.

[15] Cueto, G. M., Zebra, E. N., Picollo, M. I. 2008. "Evidence of Pyrethroid Resistance in Eggs of Pediculus humanus capitis (Phthiraptera: Pediculidae) from Argentina". Journal of Medical Entomology. Vol45(4), pp693-69. 